\section{Case Reports in Dermatology}

\title{
Bilateral Necrotizing Fasciitis of the Foot Associated with Group B Streptococcus
}

\author{
Keitaro Fukuda ${ }^{a}$ Misao Ryujin ${ }^{a}$ Reiko Sakio $^{b}$ Satoshi Fukuzumi ${ }^{b}$ \\ Takanori Omae $^{c}$ Kazuhito Hayakawa ${ }^{a}$ \\ ${ }^{a}$ Department of Dermatology, Teikyo University Chiba Medical Center, Ichihara, Japan; \\ ${ }^{b}$ Department of Plastic and Reconstructive Surgery, Teikyo University Chiba Medical \\ Center, Ichihara, Japan; 'Department of Orthopedic Surgery, Teikyo University Chiba \\ Medical Center, Ichihara, Japan
}

\section{Keywords}

Group B streptococcus · Necrotizing fasciitis, bilateral · Lower extremity · Diabetes

\begin{abstract}
Necrotizing fasciitis (NF) is a severe bacterial infection involving fascia and subcutaneous tissue. It generally affects upper or lower extremities unilaterally, and there are few reports of bilateral-extremity NF. Here, we report a case of a 43-year-old male with type 1 diabetes who had NF on the left foot and subsequently developed NF on the other foot 1 week later. The patient survived with antimicrobial therapy and bilateral below-knee amputation. As group B streptococcus (GBS) was isolated by blood culture and culture of excised tissues of both feet, bilateral GBS NF of the foot was diagnosed. GBS is a rare causative pathogen in NF; however, there have been two case reports of bilateral GBS NF of an extremity in which NF appeared on the opposite extremity 1 week after the primary site infection, as in our case. GBS was isolated from cultures of blood and excised tissues of both extremities in both cases. Together, these observations suggest that GBS has a potential to cause secondary NF at remote sites by hematogenous dissemination with approximately 1 week delay and thereby lead to bilateral NF.




\section{Introduction}

Streptococcus agalactiae, also known as group B streptococcus (GBS), is a bacterium often isolated from vaginal or rectal swab of pregnant women and long recognized as the major cause of neonatal sepsis, meningitis, and infection in pregnant women [1]. GBS is a minor pathogen of necrotizing fasciitis (NF); however, the incidence of GBS NF in nonpregnant adults with underlying disease has increased in recent years [2]. Here, we report a case of bilateral GBS NF of the foot with a unique clinical presentation and describe the clinical characteristics of GBS NF based on a review of published cases.

\section{Case Report}

A 43-year-old male with a history of type 1 diabetes presented with severe pain in both feet. Two weeks before our examination, he began to notice swelling and pain in the left sole, which gradually spread to his left lower leg. One week prior to presentation, the same symptoms began to emerge on his right sole and the dorsum of his right foot. The symptoms worsened, and he was admitted to our clinic because he had developed a fever of $39.2^{\circ} \mathrm{C}$ and was unable to walk unassisted at the time of his first visit.

On initial examination, he exhibited a reddish fluctuant cystic nodule on the dorsum of the right foot (fig. 1a), an ulcer covered with necrotic tissue on the lateral side of the right foot (fig. 1b), and swelling with redness on the dorsum of the left foot (fig. 1c). Moreover, a large callus and ulcer due to diabetic peripheral neuropathy on the right sole (fig. 1d) and streaks of necrotic skin on the left sole (fig. 1e) were observed. Laboratory analysis revealed elevated WBC $(15,100$ cells $/ \mu \mathrm{l}), \mathrm{C}$-reactive protein $(22.8 \mathrm{mg} / \mathrm{dl})$, blood glucose $(434 \mathrm{mg} / \mathrm{dl})$, hemoglobin A1c (12.2\%) and anti-GAD-antibody (350 U/ml) levels. Computed tomography showed fluid collection, suggesting a subcutaneous abscess in the dorsum of the right foot (fig. 2a), and fascial thickening associated with fat stranding in both soles (fig. 2a, b). In addition, gas shadows were detected within the deep fascia of the right sole and left sole up to the lower leg (fig. 2a, b). These results suggested the presence of NF in both feet. As the Gram stain of the exudate obtained from the necrotic skin of the left sole demonstrated the presence of Gram-positive cocci and Gram-negative rods, we suspected NF of polymicrobial origin, and the patient was empirically treated with meropenem. On the day following admission, debridement of necrotic tissues and amputation of the left fifth metatarsal bone were performed. A large amount of brownish pus was discharged from the dorsum of the right foot. Necrosis of subcutaneous tissue, fascia and muscle were observed in both feet and the lower half of the left lower leg. Culture of excised tissue of the left foot yielded GBS, group G streptococcus, and Morganella morganii. In addition, culture of excised tissue of the right foot yielded GBS, Staphylococcus aureus and Pseudomonas species. Furthermore, blood culture prior to administration of antibiotics yielded solely GBS. Based on these findings, bilateral GBS NF of the foot was diagnosed. Although debridement was repeated several times, necrosis of the fascia, muscles and bone developed in the tissues surrounding the excised parts of both feet and we were not able to control the infection. Therefore, below-knee bilateral amputation was performed 14 days after admission. After amputation, the patient has remained disease free for 8 months. 


\section{Discussion}

Including our case, 22 cases of GBS NF in nonpregnant adults have been reported in English to date (table 1) [3-16]. The mean age of patients was 54 years with a male:female ratio of 7:15. NF can be classified as type I NF due to a polymicrobial infection or type II NF due to a monomicrobial infection, and the majority of GBS NF cases were type II NF [2]. In the 22 patients, the lower extremity was the most common site of NF, accounting for approximately $70 \%$ of cases. Notably, 16 patients $(73 \%)$ had diabetes and 3 had cancer (14\%), suggesting that an immunocompromised host is a risk factor.

Our case was particularly rare in that NF occurred bilaterally and there was a time lag of 1 week between the development of primary and secondary NF. Bilateral NF is rare, and approximately 15 cases have been reported in English to date [4,16-19]. It can be caused by (i) procedures of multiple puncture, cannulation or surgery [17]; (ii) direct spreading of NF to the opposite site [18], and (iii) metastatic seeding of bacterium during the bacteremia [19].

Almost all of the reported cases, except GBS NF cases, developed bilateral NF simultaneously. Regarding bilateral GBS NF, two cases of bilateral GBS NF of an extremity have been previously reported and both cases developed secondary NF after a 1-week time lag $[4,16]$. One case developed NF on the right lower leg secondary to NF of the left lower leg [4], and the other developed NF bilaterally on upper and lower extremities secondary to septic arthritis of the left knee [16]. Of note in both cases, secondary NF appeared at remote sites several days after debridement or amputation of the primary infected lesion, and GBS was detected in blood culture even at the start of treatment for the primary infection. Thus, hematologic dissemination of GBS is an early event in the development of secondary GBS NF, and it appears that the occurrence of secondary NF with a 1-week delay is due to the slow evolution of inflammation in remote fascia and subcutaneous tissue.

Including cases of bilateral GBS NF of an extremity, GBS was detected in blood culture in $50 \%$ (11 of 22) of GBS NF cases. Importantly, patients with positive blood culture had a high mortality rate of approximately $30 \%$, whereas none of the patients with negative blood culture died (table 1). Although it is difficult to differentiate GBS NF and GBS cellulitis because the speed of evolution of GBS NF is slow, dermatologists must be aware of the characteristics of GBS NF and the possibility of appearance of secondary NF at remote sites with an approximate 1 -week delay.

\section{Statement of Ethics}

Informed consent for publishing the case was obtained from the patient.

\section{Disclosure Statement}

The authors declare no conflicts of interest.

\section{References}

Ikebe T, Chiba K, Shima T, et al: Evaluation of streptococcal toxic shock-like syndrome caused by group B streptococcus in adults in Japan between 2009 and 2013. J Infect Chemother 2015;21:207-211. 
2 Sendi P, Johansson L, Norrby-Teglund A: Invasive group B streptococcal disease in non-pregnant adults: a review with emphasis on skin and soft-tissue infections. Infection 2008;36:100-111.

-3 Riefler J 3rd, Molavi A, Schwartz D, DiNubile M: Necrotizing fasciitis in adults due to group B streptococcus. Report of a case and review of the literature. Arch Intern Med 1988;148:727-729.

4 Gardam MA, Low DE, Saginur R, Miller MA: Group B streptococcal necrotizing fasciitis and streptococcal toxic shock-like syndrome in adults. Arch Intern Med 1998;158:1704-1708.

5 Holmstrom B, Grimsley EW: Necrotizing fasciitis and toxic shock-like syndrome caused by group B streptococcus. South Med J 2000;93:1096-1098.

6 Tang WM, Ho PL, Yau WP, Wong JW, Yip DK: Report of 2 fatal cases of adult necrotizing fasciitis and toxic shock syndrome caused by Streptococcus agalactiae. Clin Infect Dis 2000;31:E15-17.

$\checkmark 7$ Crum NF, Wallace MR: Group B streptococcal necrotizing fasciitis and toxic shock-like syndrome: a case report and review of the literature. Scand J Infect Dis 2003;35:878-881.

8 Ogawa D, Shikata K, Wada J, Matsuda M, Makino H: Successful treatment of necrotizing fasciitis associated with diabetic nephropathy. Diabetes Res Clin Pract 2003;60:213-216.

-9 Blancas D, Santin M, Olmo M, Alcaide F, Carratala J, Gudiol F: Group B streptococcal disease in nonpregnant adults: incidence, clinical characteristics, and outcome. Eur J Clin Microbiol Infect Dis 2004;23:168-73.

10 Wong CH, Kurup A, Tan KC: Group B Streptococcus necrotizing fasciitis: an emerging disease? Eur J Clin Microbiol Infect Dis 2004;23:573-575.

11 Akita S, Tanaka K, Hirano A: Lower extremity reconstruction after necrotising fasciitis and necrotic skin lesions using a porcine-derived skin substitute. J Plast Reconstr Aesthet Surg 2006;59:759-763.

12 Bero SM, Brady MS: Streptococcal septic shock after inguinal lymphadenectomy. Surg Infect 2006;7:547-550.

13 Wong CH, Song C, Ong YS, Tan BK, Tan KC, Foo CL: Abdominal wall necrotizing fasciitis: it is still "Meleney's Minefield". Plast Reconstr Surg 2006;117:147e-150e.

14 Lee S, Roh KH, Kim CK, et al: A case of necrotizing fasciitis due to Streptococcus agalactiae, Arcanobacterium haemolyticum, and Finegoldia magna in a dog-bitten patient with diabetes. Korean J Lab Med 2008;28:191-195.

15 Hung T, Zaghi S, Yousefzadeh J, Leibowitz M: Necrotizing Fasciitis Associated with Staphylococcus lugdunensis. Case Rep Infect Dis 2012;2012:453685.

16 Umemura H, Hiragushi K, Sasaki S, et al: A male with group B streptococcal necrotizing fasciitis at multiple sites secondary to multifocal septic arthritis. Acta Derm Venereol 2015;95:614-615.

17 Kothari A, Shah YR, Floyd AS: Bilateral upper limb necrotizing fasciitis caused by Staphylococcus aureus. J Foot Ankle Surg 2014;53:187-190.

18 Rehman T, Moore TA, Seoane L: Serratia marcescens necrotizing fasciitis presenting as bilateral breast necrosis. J Clin Microbiol 2012;50:3406-3408.

19 Ho PL, Tang WM, Yuen KY: Klebsiella pneumoniae necrotizing fasciitis associated with diabetes and liver cirrhosis. Clin Infect Dis 2000;30:989-990. 


\section{Case Reports in Dermatology}

\begin{tabular}{l|l}
\hline Case Rep Dermatol 2016;8:243-249 \\
\hline DOI: $10.1159 / 000448163$ & $\begin{array}{l}\text { C } 2016 \text { The Author(s). Published by S. Karger AG, Basel } \\
\text { www.karger.com/cde }\end{array}$ \\
\hline
\end{tabular}
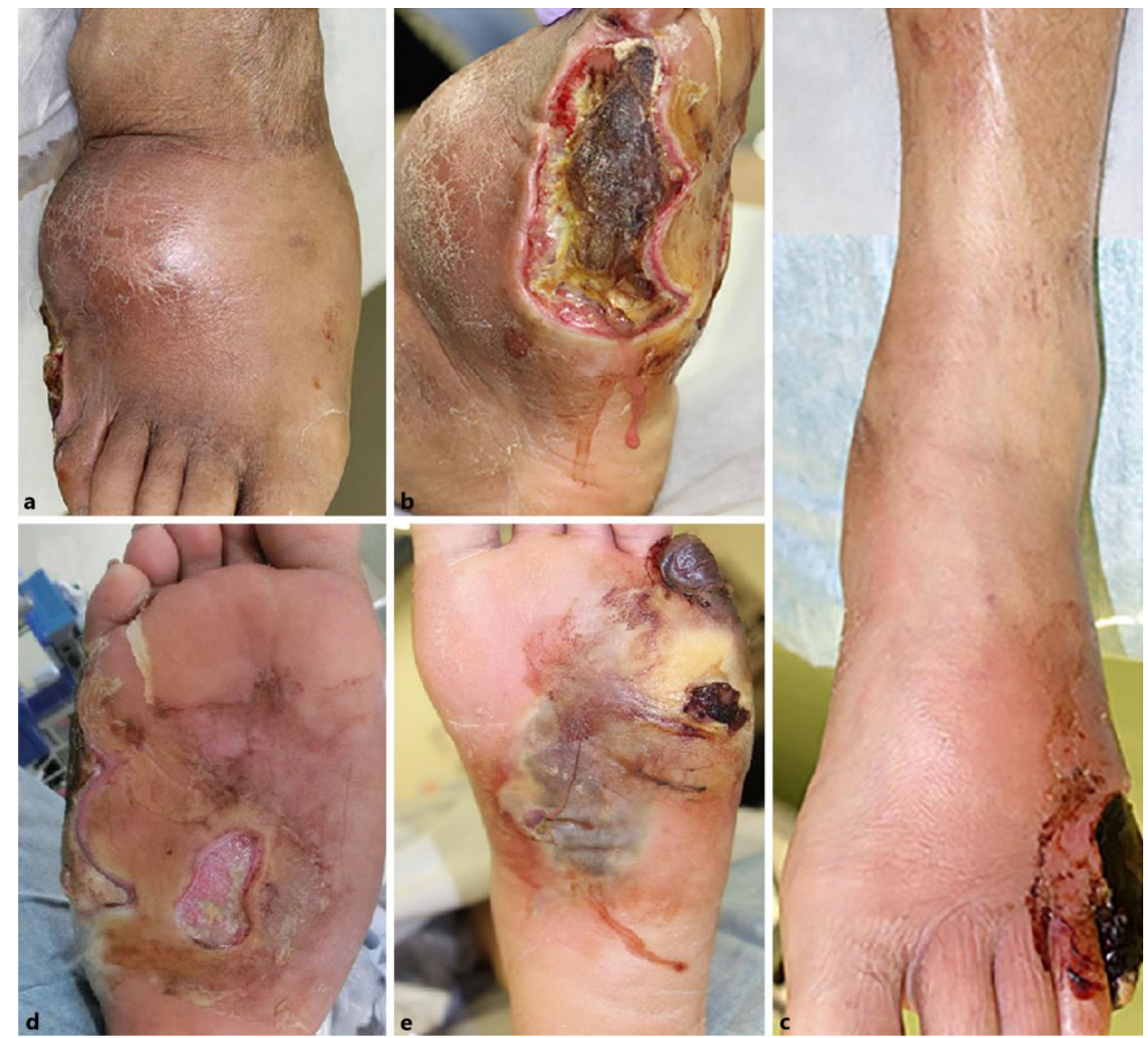

Fig. 1. Clinical findings at the initial physical examination. a Fluctuant cystic mass with redness on the dorsum of the right foot. b Ulcer with necrotic tissue on the lateral side of the right foot. c Swelling and redness on the dorsum of the left foot and medial side of the left ankle. $\mathbf{d}$ Ulcer and callus on the right sole. e Necrosis of the left small toe and streaks of dusky skin on the left sole. 


\section{Case Reports in Dermatology}

\begin{tabular}{l|l}
\hline Case Rep Dermatol 2016;8:243-249 \\
\hline DOI: $10.1159 / 000448163$ & $\begin{array}{l}\text { C 2016 The Author(s). Published by S. Karger AG, Basel } \\
\text { www.karger.com/cde }\end{array}$ \\
\hline
\end{tabular}

Fukuda et al.: Bilateral Necrotizing Fasciitis of the Foot Associated with Group B Streptococcus
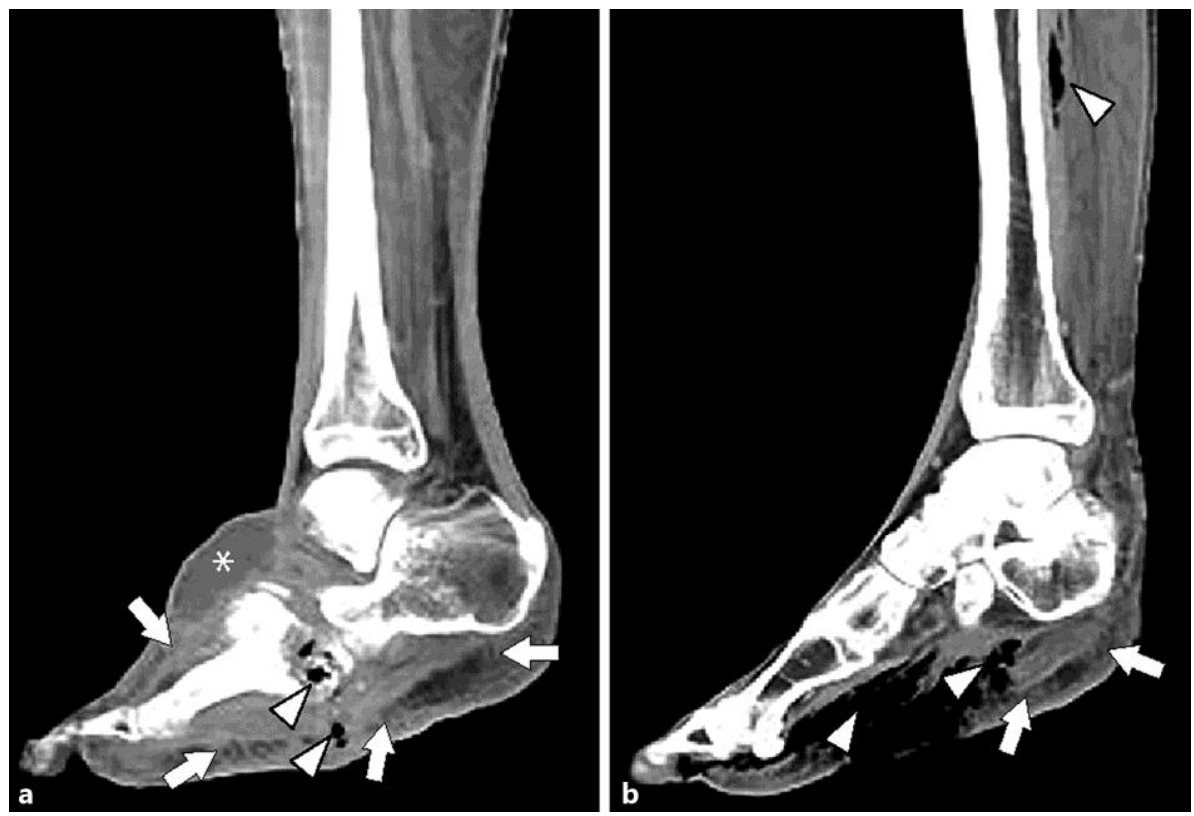

Fig. 2. Computed tomography scans of right (a) and left (b) lower extremity. Subcutaneous abscess is shown (asterisk) on the dorsum of the right foot. Arrows indicate fascial thickening with fat stranding, and arrowheads indicate soft-tissue emphysema. 
Table 1. Published reports of GBS NF

\begin{tabular}{|c|c|c|c|c|c|c|}
\hline First author & $\begin{array}{l}\text { Age, years/ } \\
\text { sex }\end{array}$ & $\begin{array}{l}\text { Type } \\
\text { of NF }\end{array}$ & $\begin{array}{l}\text { Underlying } \\
\text { condition }\end{array}$ & Site(s) affected & $\begin{array}{l}\text { Results of } \\
\text { blood culture }\end{array}$ & $\begin{array}{l}\text { Prog- } \\
\text { nosis }\end{array}$ \\
\hline Riefler [3] & $51 / F$ & II & diabetes & foot to lower leg & - & alive \\
\hline \multirow[t]{3}{*}{ Gardam [4] } & $67 / F$ & II & cancer & $\begin{array}{l}\text { left lower leg } \rightarrow \\
\text { bilateral lower leg }\end{array}$ & + & dead \\
\hline & $51 / \mathrm{M}$ & II & diabetes & genitalia & - & alive \\
\hline & $34 / \mathrm{M}$ & II & diabetes & lower leg & - & alive \\
\hline Holmstrom [5] & $52 / \mathrm{F}$ & II & diabetes & genitalia & + & alive \\
\hline \multirow[t]{2}{*}{ Tang [6] } & $75 / F$ & II & - & lower leg & ND & dead \\
\hline & $64 / \mathrm{M}$ & II & $\begin{array}{l}\text { diabetes, liver } \\
\text { cirrhosis }\end{array}$ & thigh & + & dead \\
\hline Crum [7] & $43 / \mathrm{M}$ & II & diabetes & thigh & ND & alive \\
\hline Ogawa [8] & $50 / \mathrm{F}$ & II & diabetes & thigh & + & alive \\
\hline Blancas [9] & $43 / F$ & II & cancer & ND & + & dead \\
\hline \multirow[t]{5}{*}{ Wong [10] } & $48 / F$ & II & diabetes & thigh & - & alive \\
\hline & $66 / F$ & II & diabetes & foot to lower leg & - & alive \\
\hline & $44 / F$ & II & diabetes & lower leg & - & alive \\
\hline & $51 / \mathrm{F}$ & II & diabetes & lower leg & + & alive \\
\hline & $38 / F$ & II & - & hand & + & alive \\
\hline Akita [11] & $68 / \mathrm{M}$ & II & diabetes & ND & ND & ND \\
\hline Bero [12] & $67 / F$ & II & cancer & lower leg to thigh & + & alive \\
\hline Wong [13] & $66 / F$ & II & diabetes & abdomen & - & alive \\
\hline Lee [14] & $36 / F$ & I & diabetes & foot & + & alive \\
\hline Hung [15] & $66 / F$ & I & diabetes & genitalia & - & alive \\
\hline Umemura [16] & $63 / \mathrm{M}$ & II & - & $\begin{array}{l}\text { left knee } \rightarrow \text { right } \\
\text { foot, left thigh, right } \\
\text { forearm, left arm }\end{array}$ & + & alive \\
\hline Current case & $43 / \mathrm{M}$ & I & diabetes & $\begin{array}{l}\text { left foot } \rightarrow \text { right foot, } \\
\text { left foot to lower leg }\end{array}$ & + & alive \\
\hline
\end{tabular}

$\mathrm{ND}=$ Not described . 